\title{
Pengaruh Komitmen Organisasi dan Keterikatan Kerja Terhadap Loyalitas Aktivis Muhammadiyah dan Organisasi Otonom pada Tingkat Pusat
}

\author{
Elyusra Muallimin | Bambang Dwi Hartono | Ahmad Diponegoro
}

How to cite : Muallimin, E.,, Hartono, B., D.\& Diponegoro, A.,(2020). Pengaruh Komitmen Organisasi dan Keterikatan Kerja Terhadap Loyalitas Aktivis Muhammadiyah dan Organisasi Otonom pada Tingkat Pusat. 1(1). Jurnal Jurnal Manajemen Bisnis dan Publik(JMBP). 32-40.

To link to this article : https://doi.org/10.22236/jmbp.v1i1.5705

Opened Access Article

Published Online on 12 November 2020

Submit your paper to this journal 
Recieved: 09 Oktober 2020

Accepted: 2 November 2020

Published: 12 November 2020

${ }^{*}$ Corresponding author: Elyusra Muallimin, Universitas Muhammadiyah Prof Dr Hamka, Indonesia

E-mail:

elyusra_muallimin@uhamka.ac.id

Reviewing editor:

Bambang Dwi Hartono, Universitas Muhammadiyah Prof. DR. HAMKA- Jakarta.

Additional information is available at the end of the article

\title{
Pengaruh Komitmen Organisasi dan Keterikatan Kerja Terhadap Loyalitas Aktivis Muhammadiyah dan Organisasi Otonom pada Tingkat Pusat
}

\author{
Elyusra Muallimin*, Bambang Dwi Hartono, Ahmad Diponegoro
}

Abstract. T Abstrak. Penelitian ini bertujuan untuk mengetahui pengaruh komitmen organisasi dan keterikatan kerja terhadap loyalitas organisasi pada aktivis Muhammadiyah dan organisasi otonom tingkat pusat di Jakarta. Metode yang digunakan adalah metode kuantitatif. Teknik pengumpulan data menggunakan kuesioner. Populasi pada penelitian ini berjumlah 78 responden. Analisis jalur komitmen organisasi terhadap Loyalitas organisasi sebesar $\rho \_31=0,725$ memiliki tingkat korelasi kuat. Analisis jalur Keterikatan Kerja terhadap Loyalitas organisasi sebesar $\rho \_32=0,207$ memiliki tingkat korelasi rendah. Analisis jalur komitmen orgnisasi terhadap keterikatan kerja sebesar $\rho \_21=0,457$ memiliki tingkat korelasi sedang. Dari ketiga hipotesis ini berarti $\mathrm{Ha}$ dan $\mathrm{HO}$ di terima. Berdasarkan perhitungan korelasi antar dimensi, diperoleh dimensi Komitmen Normatif pada komitmen organisasi memiliki tingkat pengaruh lebih tinggi terhadap loyalitas organisasi sebesar 0,760 , lalu dimensi rasa memiliki pada keterikatan kerja juga memiliki tingkat pengaruh lebih tinggi terhadap loyalitas organisasi sebesar 0,729. Dan komitmen normatif memiliki pengaruh lebih tinggi terhadap keterikatan kerja sebesar 0,733 . Ada hubungan keterikatan kerja Aktivis Muhammadiyah di tingkat pusat terhadap Loyalitas organisasi yang positif dan signifikan akan tetapi korelasinya cukup rendah sehingga dapat berimplikasi pada hasil kinerja aktivis Muhammadiyah dan organisasi otonom dalam menjalankan misi organisasi..

Kata Kunci: Komitmen Organisasi, Keterikatan Kerja, Loyalitas Organisasi .

\section{TENTANG PENULIS}

Elyusra Muallimin adalah mahasiswa pascasarjana UHAMKA yang lulus pada tahun 2020. la saat ini sedang aktif dalam penelitian-penelitian yang terkait dengan manajemen organisasi pada aspek sumber daya manusia.

Bambang Dwi Hartono adalah Dosen Sekolah Pascasarjana Universitas Muhammadiyah Prof. DR. HAMKA pada program studi Magister Manajemen. la saat ini sedang aktif dalam berbagai penelitian terkait dengan manajemen dan bisnis pada kebijakan publik.

Ahmad Diponegoro adalah Dosen Sekolah Pascasarjana Universitas Muhammadiyah Prof. DR. HAMKA pada program studi Magister Manajemen. la saat ini sedang aktif dalam berbagai penelitian terkait dengan manajemen dan bisnis pada kebijakan publik.

\section{PENELITIAN SEBELUMNYA}

Penelitian sebelumnya membahas kajian manajemen terkait pemasaran produk-produk UMKM dengan diferensiasi produk agar menembus pasar global. Fokus pada kepemimpinan sumber daya manusia dalam meningkatan produktifitas. Saat ini peneliti membahas Pengaruh Komitmen Organisasi dan Keterikatan Kerja Terhadap Loyalitas Aktivis Muhammadiyah dan Organisasi Otonom pada Tingkat Pusat. 


\section{Pendahuluan}

Bagi yang baru mengenal Muhammadiyah pasti beranggapan organisasi ini adalah organisasi besar, kaya, lembaga charity dan terkenal loyal para anggotanya. Anggapan seperti ini muncul dari pernyataan beberapa Kepala Daerah yang mengakui bila ada bencana alam kader Muhammadiyah selalu tampil terdepan membantu. Ditengah persepsi publik yang positip seperti ini, sebenarnya Muhammadiyah memiliki masalah dan tantangan yang semakin komplek, diantaranya agenda internal Muhammadiyah yaitu perhatian dan fokus dalam mengurus Muhammadiyah, Hal ini disampaikan oleh Ketua Umum PP Muhammadiyah pada Majalah Suara Muhammadiyah tentang jumlah anggota yang cenderung stagnan, pengelolaan organisasi seadanya dan konflik dalam pengelolaan amal usaha. Pekerjaan rumah ini semuanya menuntut komitmen seluruh pimpinan dan anggota disemua tingkatan. (Haedar Nashir, 2019)

Permasalahan lain di internal Muhammadiyah saat ini tentang employee enggagement dan loyalitas terhadap organisasi. Fenomena ini dibenarkfhan oleh PP Nasyiatul Aisyiyah saat ini, bahwa kurangnya loyalitas aktivis terlihat dari keterlibatannya dalam berbagai kegiatan organisasi yang diadakan. Termasuk masih rendahnya kehadiran aktivis dalam rapat rutin yang di adakan. Padahal untuk mendukung setiap program kerja organisasi jangka pendek maupun jangka panjang dibutuhkan banyak aktivis, kader dan anggota yang bisa menyebarkan program secara massif disemua tingkatan struktur organisasi Muhammadiyah. Muhammadiyah saat ini memasuki awal abab ke-2, para pimpinan harus benar-benar memikirkan, berkomitmen, dan bertanggungjawab dalam menghadapi masalah dan agenda Muhammadiyah yang berat itu agar gerakan Islam ini semakin berkemajuan.

Anggota organisasi merupakan elemen penting dalam menjalankan sebuah organisasi. Sebuah organisasi dapat dikatakan efektif apabila organisasi tersebut telah mampu mencapai tujuan yang di buat oleh organisasi itu sendiri. Sedangkan keberhasilan suatu organisasi dalam mencapai tujuannya juga ditentukan dari SDM dan kontribusinya dalam menjalankan organisasi tersebut. Kontribusi akan maksimal jika setiap SDM memiliki engagement yang tinggi pada organisasi tersebut. Engagement didefinisikan sebagai sikap positif yang ditunjukan anggota organisasi terhadap organisasi dan nilai organisasi (Robinson D., S. Perryman, 2004)

Employee engagement yang tinggi dari anggota organisasi, menyebabkan anggota organisasi memiliki kesadaran terhadap jobdesc dan teman dalam organisasi untuk meningkatkan performance dalam pekerjaan demi tujuan organisasi. Selain aspek komitmen organisasi dan employee enggagement aspek-aspek perwujudan loyalitas individu oleh Siswanto (Trianasari, 2005) terhadap aspek lain yaitu taat pada peraturan, kemauan untuk bekerja sama, rasa memiliki, dan kesukaan terhadap pekerjaan. Dari beberapa aspek diatas maka peneliti membatasi permasalahan pada 2 aspek yaitu komitmen organisasi dan employee enggagement sebagai faktor-faktor yang lebih penting dalam meningkatkan loyalitas para aktifis Muhammadiyah dan para pengurus organisasi otonom di tingkat pusat. Mengapa demikian ? komitmen pimpinan harus tetap dibutuhkan dalam rangka memikirkan agenda penting berikutnya. Muhammadiyah tidak cukup berada dalam zona nyaman jika ingin terus maju menjadi gerakan islam.

Kemudian faktor Engagement selama ini dikenal luas sebagai konsep yang dapat memberikan informasi mengenai tingkat keterikatan anggota, faktor yang mendorong anggota organisasi melakukan usaha yang maksimal serta faktor mempengaruhi keputusan anggota organisasi untuk bertahan atau meninggalkan organisasi. Employee engagement merupakan sebuah konsep manajemen SDM yang menyatakan anggota organisasi dengan engagement tinggi adalah anggota yang memiliki keterlibatan penuh dan memiliki semangat bekerja tinggi dalam pekerjaanya. Fenomena diatas, komitmen organisasi dan employee enggagement menjadi sangat penting/urgensi perlu diteliti bagaimana loyalitas para aktifis dan para pengurus Pimpinan Ortom ditingkat pusat bila diukur oleh 2 variabel ini. 


\section{Kajian Teori}

\subsection{Loyalitas Organisasi :}

Menurut (Dosenpendidikan.co.id, 2014) Loyalitas dapat diartikan tekad dan kesanggupan menaati, melaksanakan, dan mengamalkan sesuatu dengan disertai penuh kesadaran dan tanggung jawab. Tekad dan kesanggupan tersebut harus dibuktikan dalam sikap dan tingkah laku sehari-hari serta dalam pelaksanaan tugas. Loyalitas anggota terhadap organisasi memiliki makna kesediaan seseorang untuk melenggangkan hubungannya dengan organisasi, kalau perlu mengorbankan kepentingan pribadinya tanpa mengharapkan apapun. Loyalitas anggota memegang peranan krusial dalam jalannya organisasi. Tata aturan yang sempurna, program kerja yang brilian, tanpa disertai dengan loyalitas para eksekutornya adalah hal yang sia-sia. Secara lebih riil, anggota tersebut akan menaati segala bentuk tata tertib yang berlaku, mendukung program kerja dengan mengikutsertakan diri sebagai partisipan aktif. Bahkan menjadi pengurus/kreator ide-ide penting untuk membangun organisasi dari dalam.

Loyalitas yang dimilki oleh setiap organisator juga berpengaruh pada kelanjutan suatu organisasi dalam melaju pada rel visi dan misi. Jika suatu organisasi sudah melenceng dari jalur visi dan misi yang ada, besar kemungkinan bahwa rasa loyalitas yang dimilki oleh para anggotanya telah kropos dan lapuk. Karena jika memang loyalitas benar-benar ada pada setiap anggota, tidak mungkin mereka akan membiarkan dan bahkan membawa organisasi tersebut ke arah yang menyimpang dari rel visi dan misi. Menurut Oliver (dalam Taylor, Celuch, dan Goodwin,1999:218) Loyalitas adalah sebagai komitmen yang tinggi untuk membeli kembali suatu produk atau jasa yang disukai di masa mendatang, disamping pengaruh situasi dan usaha pemasar dalam merubah perilaku. Dengan kata lain konsumen akan setia untuk melakukan pembelian ulang secara terusmenerus. Gramer dan Brown (dalam Utomo 2006:27) Loyalitas adalah derajat sejauh mana seorang konsumen menunjukkan perilaku pembelian berulang dari suatu penyedia jasa, memiliki suatu desposisi atau kecenderungan sikap positif terhadap penyedia jasa, dan hanya mempertimbangkan untuk menggunakan penyedia jasa ini pada saat muncul kebutuhan untuk memakai jasa ini. Dari definisi yang disampaikan Gramer dan Brown, konsumen yang loyal tidak hanya seorang pembeli yang melakukan pembelian berulang, tetapi juga mempertahankan sikap positif terhadap penyedia jasa.

\subsection{Aspek-Aspek Loyalitas}

Untuk mengetahui apakah seorang anggota loyal terhadap organisasi. Terdapat beberapa aspek yang dapat digunakan untuk mengukur loyalitas anggota tersebut. Aspek-aspek loyalitas menurut siswanto dalam (Trianasari,2005) antara lain:

a. Taat pada peraturan.

Seorang anggota yang loyal akan selalu taat pada peraturan. Sesuai dengan pengertian loyalitas, ketaatan ini timbul dari kesadaran anggota jika peraturan yang dibuat oleh organisasi semata-mata disusun untuk memperlancar jalannya pelaksaan untuk mencpai tujuaan organisasi. Kesadaran ini membuat anggota akan bersikap taat tanpa merasa terpaksa atau takut terhadap sanksi yang akan diterimanya apabila melanggar peraturan tersebut.

b. Tanggung jawab pada organisasi.

Ketika seorang anggota memiliki sikap sesuai dengan pengertian loyalitas, maka secara otomatis ia akan merasa memiliki tanggung jawab yang besar terhadap organisasinya. Anggota akan berhati-hati dalam mengerjakan tugas-tugasnya, namun sekaligus berani untuk mengembangkan berbagai inovasi demi kepentingan organisasi.

c. Kemauan untuk bekerja sama. 
Anggota yang memiliki sikap sesuai dengan pengertian loyalitas, tidak segan untuk bekerja sama dengan anggota lain. Bekerja sama dengan orang lain dalam suatu kelompok memungkinkan seorang anggota mampu mewujudkan impian organisasi untuk dapat mencapai tujuan yang tidak mungkin dicapai oleh seorang anggota secara invidual

d. Rasa memiliki

Adanya rasa ikut memiliki anggota terhadap organisasi akan membuat anggota memiliki sikap untuk ikut menjaga dan bertanggung jawab terhadap organisasi sehingga pada akhirnya akan menimbulkan sikap sesuai dengan pengertian loyalitas demi tercapainya tujuan organisasi.

e. Hubungan antar pribadi

Anggota yang memiliki loyalitas kerja tinggi akan mempunyai hubungan antar pribadi yang baik terhadap anggota lain dan juga terhadap atasannya. Sesuai dengan pengertian loyalitas, hubungan antar pribadi ini meliputi hubungan sosial dalam pergaulan sehari-hari, baik yang menyangkut hubungan kerja maupun kehidupan pribadi.

f. Kesukaan terhadap tugas

Sebagai manusia, anggota pasti akan mengalami masa-masa jenuh terhadap tugas yang dilakukannya setiap hari. Seorang anggota yang memiliki sikap sesuai dengan pengertian loyalitas akan mampu menghadapi permasalahan ini dengan bijaksana. Hal ini hanya dapat dilakukan apabila seorang anggota mencintai tugasnya.

g. Komitmen Organisasi :

Tingginya komitmen yang dimiliki pada organisasi akan menaikkan minat dan tanggung jawab yang harus ia lakukan dalam melakukan pengembangan organisasi tanpa melihat kepentingannya sendiri, dengan hal ini ia akan selalu mengutamakan kepentingan organisasi dibandingkan dengan kepentingannya sendiri. Krisna (2007:2) mengarahkan opininya pada keadaan di mana seorang individu loyal dan memperlihatkan kesetiaan kerja pada organisasi. Komitmen ini ditunjukkan melalui kekuatan yang saat relatif bisa tinggi dan justru melemah hal ini didasarkan pada keterlibatan organisasi itu sendiri. Komitmen sendiri biasanya diartikan melalui sifat yang di miliki para anggota karakteristik intelektual yang dimiliki, yang dalam hal ini tidak dapat dipengaruhi oleh kalangan luar. Tingginya komitmen yang dimiliki pada organisasi akan menaikkan minat dan tanggung jawab yang harus ia lakukan dalam melakukan pengembangan organisasi tanpa melihat kepentingannya sendiri, dengan hal ini ia akan selalu mengutamakan kepentingan organisasi dibandingkan dengan kepentingannya sendiri.(Purnama et al., 2020)

\subsection{Dimensi Komitmen Organisasi :}

Adapun dimensi komitmen organisasi menurut Allen dan Meyer dalam Darmawan (2013:169) ada 3 dimensi organisasi yaitu :

a. Afektif Komitmen

Affective commitment adalah kepercayaan yang dibangun pada nilai-nilai organisasi serta adanya keterikatan yang kuat antar emosional yang dimiliki dengan kepercayaan tersebut.

- adanya peningkatan karier yang diinginkan seluruh anggota organisasi

- memiliki rasa percaya yang tinggi pada organisasi tempat di mana ia bekerja

- senantiasa setia dan mengabdikan dirinya hanya untuk mengembangkan organisasi

b. Komitmen Berkelanjutan

Komitmen berkelanjutan (continuance commitment), adalah kesadaran yang dimiliki setiap individu terlepas dari emosional yang dimiliki semata, karena para anggota telah menerawang 
lebih jauh akan kerugian yang bisa mereka alami ketika hendak meninggalkan organisasi tempat di mana ia bekerja.

- organisasi yang sangat dicintai dan dijunjung tinggi

- adanya keyakinan dan keinginan untuk bertahan dalam organisasi

- kepentingan pribadi lebih dikesampingkan karena kepentingan organisasi lebih utama.

- adanya keterikatan dan ketertarikan yang dipancarkan oleh perusahaan sehingga para anggota dengan mudah loyal pada perusahaan.

- tidak rela jika harus meninggalkan pekerjaan yang telah dijalaninya

c. Komitmen Normatif

Komitmen normatif (normative commitment) berbeda dengan afektif dan berkelanjutan, normatif ini merupakan tata aturan yang memang seharusnya diterapkan pada organisasi mengingat tidak semua organisasi mampu memiliki komitmen yang tinggi pada organisasi.

\subsection{Employee Enggagement}

Employee engagement, adalah keterikatan atau keterlibatan dan rasa antusias terhadap pekerjaan dan tempat beraktifitas. Dengan Employee engagement yang tinggi anggota akan memiliki rasa loyalitas yang lebih tinggi dan memberikan kontribusi yang lebih banyak bagi organisasi. Para anggota organisasi yang mempunyai engagement yang tinggi akan melakukan hal positif dan kesadaran terhadap organisasi sehingga kinerja sesuai tata kerja yang sudah ditentukan sesuai dengan Anggaran Dasar dan Anggaran Rumah Tangga yang ada. Menurut (Anitha, 2014) mendefinisikan employee engagement secara umum sebagai tingkat komitmen dan keterlibatan karyawan terhadap suatu organisasi dan nilai-nilai dalam organisasi tersebut. Ketika seorang karyawan terlibat, dia menyadari tanggung jawabnya dalam tujuan bisnis. Di samping itu karyawan tersebut juga memotivasi rekan-rekannya untuk mencapai kesuksesan tujuan organisasi.

Sikap positif anggota dengan tempat kerja atau aktifitasnya dan sistem nilai di dalam tempat kerja tersebut disebut sebagai hubungan emosional positif anggota terhadap pekerjaannya. Anggota yang engaged (terikat) pada pekerjaannya adalah karyawan yang melampaui tuntutan tugas rata-rata dengan melakukan peran mereka di dalam tugas yang diamanahkan tersebut secara unggul. Fleming \& Asplund (2007) menyajikan empat dimensi employee engagement model Gallup sebagai gambar berikut:

FOUR DIMENSIONS OF

EMPLOYEE ENGAGEMENT

mong the many variables that discriminate between highly productive workplaces and those that are unproductive is the quality of the local workplace manager and his or her ability to meet a core set of employees' emotional requirements. Work units that meet these conditions of engagement perform at a much higher level than work units that fail to

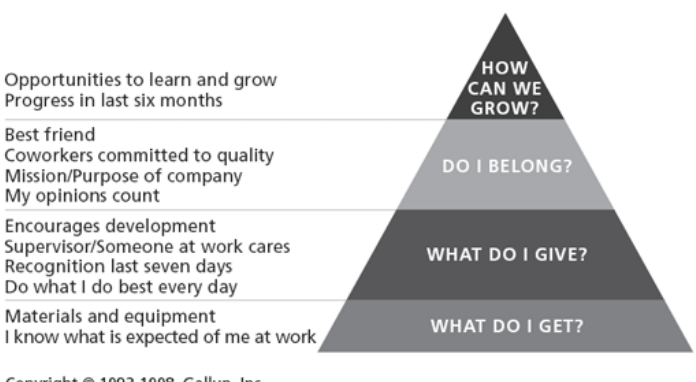

Copyright @ 1993-1998 Gallup, Inc.

Gambar 1: Dimensi Employee Engagement Versi Gallup Sumber Data Diolah (2020) 
Dimensi employee engagement pada pyramid Gallup tersebut terdiri dari tingkatan pemenuhan kebutuhan karyawan, tingkatan kontribusi karyawan yang telah diberikan, tingkatan karyawan merasa memiliki, serta tingkatan kesempatan karyawan untuk tumbuh. (Sugiharto \& Devie, 2015). Secara detail dari 4 (empat) dimensi di atas: (a) Tingkatan pertama dimensi employee engagement yaitu -What do I get? yang menjelaskan tentang kebutuhan dasar (basic need) berbagai fasilitas yang dibutuhkan oleh seorang anggota untuk berkontribusi kepada organisasi.; (b) Tingkatan kedua menjelaskan mengenai -What do I give, yaitu terkait dengan dimensi dukungan manajemen (management support) di dalam organisasi tempat anggota beraktifitas ; (c) Tingkatan ketiga yaitu -Do I belong? yang menjelaskan dimensi employee engagement yaitu rasa memiliki (belongness) dimana dimensi ini memperlihatkan seorang anggota yang merasa bahwa dirinya benar-benar diterima di dalam organisasi; (d) Tingkatan keempat, yaitu - How we can grow? yang menjelaskan dimensi belajar dan bertumbuh (development and grow) pada anggota.

\section{Metode Penelitian}

Penelitian dilaksanakan di Pimpinan Pusat Muhammadiyah dan Organisasi Otonomi periode 2015-2020. Penelitian ini dilaksanakan selama 6 (enam) bulan. Dengan Metode Penelitian menggunakan penelitian eksplanatif, karena penelitian ini bertujuan menganalisis hubunganhubungan antara satu variabel dengan variabel lain atau bagaimana suatu variabel mempengaruhi variabel yang lain. Kemudian Bentuk Penelitian Kuantitatif, Dalam penelitian ini peneliti akan mengukur variebel komitmen organisasi dan employee engagement terhadap loyalitas organisasi, selanjutnya data yang dihasilkan akan di uji dengan menggunakan formula moment untuk mengetahui besaran koefisien korelasinya dan menentukan signifikan tidaknya hubungan kedua variabel tersebut. Untuk itu jenis penelitian ini termasuk dalam jenis penelitian korelasional, hal ini sebagaimana dinyatakan oleh Price dan Creswell bahwa penelitian korelasional merupakan jenis penelitian non-experimental dimana peneliti mengukur tiga variabel dan menilai hubungan statistik (yaitu korelasi) antara mereka dengan sedikit atau tidak ada usaha untuk mengendalikan variabel asing. Jadi peneliti mengkaji fakta-fakta yang telah terjadi dan dialami oleh subjek penelitian. Artinya peneliti hanya menggali fakta-fakta dari peristiwa yang telah terjadi dengan menggunakan angket yang berisi sejumlah pertanyaan atau pernyataan yang merefleksikan persepsi responden terhadap variabel yang diteliti.

Populasi dan Sampel, Populasi dalam penelitian yang penulis lakukan adalah para pengurus / aktifis Pimpinan Pusat Muhammadiyah dan Ortomnya periode 2015-2020, Sehingga populasi yang diambil dalam penelitian ini berjumlah 318 responden. Sampel adalah sebagai jumlah sebagian dari populasi yang kedudukannya mewakili populasi dan dijadikan sumber pengumpulan data penelitian. Untuk menghitung penentuan jumlah sampel dari populasi tertentu, maka digunakan rumus Slovin sebagai berikut

Di mana:

$\mathrm{n}=$ sampel

$\mathrm{N}=$ populasi

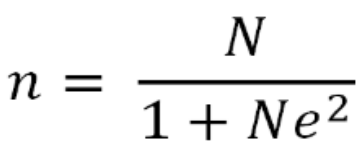

$\mathrm{e}=$ margin kesalahan

Dalam menentukan jumlah sampel yang akan dipilih, menggunakan tingkat kesalahan sebesar $5 \%$ dan pemilihan sampel dari setiap Institusi/Organisasi dilakukan secara acak. Jumlah populasi yang digunakan adalah 318 orang, dengan perhitungan sebagai berikut:

$$
n=\frac{N}{1+N e^{2}}
$$




\section{$\mathrm{n}=318:(1+(318 \times 0,0025))=117,158$ dibulatkan menjadi 117 sampel}

Teknik pengumpulan data yang digunakan untuk penulisan tesis ini dilakukan melalui dua cara meliputi: Studi Kepustakaan dan Tehnik Kuisioner (google doc). Hasil pengumpulan data selanjutnya dianalisa dengan mendeskripsikan data meliputi Mean (M), Median (Me), Modus (Mo), dan Standar deviasi (SD). Sebelum pengujian hipotesis dilakukan pengujian prasyarat analisis yang meliputi uji normalitas, uji linieritas, dan uji multikolinieritas.

Pengujian Hipotesis melalui : a).Analisis Regresi Berganda . Analisis ini digunakan untuk mengetahui besarnya pengaruh yang ada antara gaya kepemimpinan terhadap Kinerja pegawai. Persamaan umum regresi berganda yaitu: $X 3=C+\beta X 1+\beta X 2+R$ Dimana: $X 1=$ gaya kepemimpinan, $\mathrm{X} 2=$ Employee Engagement, $\mathrm{X} 3=$ Kinerja pegawai. $\mathrm{C}=$ konstanta $\beta=$ konstanta regresi $R=$ residual . b).Koefisien Determinasi ( $R 2$ ). Koefisien Determinasi ( $R 2$ ) pada intinya digunakan untuk mengukur seberapa jauh kemampuan model regresi dalam menerangkan variasi variabel dependen (Ghozali, 2009). Peneliti menggunakan adjusted $R 2$ untuk mengevaluasi mana model regresi terbaik. Nilai $\mathrm{R} 2$ dapat naik atau turun apabila satu variabel independen ditambah ke dalam model. Koefisien determinasi (R2 ) dinyatakan dalam persentase yang nilainya berkisar antara $0<$ R2 $<1$. Nilai R2 yang kecil berarti kemampuan variabel-variabel independen dalam menjelaskan variasi variabel dependen amat terbatas. Nilai yang mendekati satu berarti variabelvariabel independen memberikan hampir semua informasi yang dibutuhkan untuk memprediksi variasi variabel dependen. c).Analisis Jalur. Analisis jalur didasarkan pada teknik regresi sederhana, tetapi memungkinkan pemahaman yang lebih kaya tentang hubungan antara dan di antara yang variabel diperiksa (Kellar \& Kelvin, 2013). Regresi berganda sederhana memungkinkan prediksi, berdasarkan sekumpulan variabel X. Analisis jalur ini dibangun untuk memeriksa keduanya efek langsung dan tidak langsung dari berbagai variabel $\mathrm{X}$.

\section{Hasil dan Pembahasan}

Kuesioner yang disebar ke sejumlah 78 responden dari 117 orang sebagai populasi, dengan butir pernyataan atau pertanyaan dari Variabel Loyalitas sebanyak 26 butir, untuk Variabel Komitmen organisasi sebanyak 16 butir, dan untuk Variabel Keterikatan kerja sebanyak 18 butir, dengan menggunakan analisis statistik deskriptif. Data yang dikumpulkan dari variabel yang terdiri dari 3 variabel , 2 variabel indevenden yaitu variabel Komitmen organisasi , dan Keterikatan kerja, serta 1 variabel dependen yaitu variabel Loyalitas anggota. Untuk menggambarkan indeks dari jawaban responden maka, digunakan analisis deskriptif, dari berbagai konstruk yang dikembangkan dan statistik diferensial untuk pengujian hipotesis, khususnya dengan menggunakan SPSS 25. Dari karakteristik jenis kelamin responden, terlihat bahwa responden lakilaki sebanyak 45 orang dengan presentase sebesar $58 \%$ dan responden perempuan yaitu sebanyak 38 orang dengan presentasi sebesar $42 \%$.dengan prosentase dominan $45 \%$ adalah usia 30 s.d. 40 tahun yaitu sebanyak 35 orang. Tingkat pendidikan terakhir atau yang sedang diikuti Responden tentu tidak sama atau beragam, sehingga akan mencerminkan sebuah pola pikir yang berbeda dan akan mempengaruhi perilaku tiap individu dalam melakukan sesuatu, jenjang pendidikan tersebut di di dominasi oleh responden yang berpendidikan $\mathrm{S} 1$ sebanyak orang yaitu sebesar $60 \%$.

Hasil uji validitas dan uji reliabilitas Untuk menguji uji validitas dan reliabilitas menggunakan bantuan SPSS 24 dengan melihat nilai Scale Corrected Item-Total Correlation, nilai tersebut adalah nilai Validitas Butir. Sedangkan nilai Croncbach's Alpha if Item Deleted adalah nilai Reliabilitas Butir. Untuk menilai apakah nilai-nilai di atas (Validitas Butir dan Reliabilitas Butir) valid dan reliabel, bandingkan dengan $\mathrm{R}$ Tabel Pada $\mathrm{DF}=\mathrm{N}-2$ dan Probabilitas 0,05 . Nilai $\mathrm{DF}$ dalam contoh ini: jumlah sampel (30)-2=28. R Tabel pada DF 28 Probabilitas 0,05 adalah 0,3610 
Contoh untuk item soal nomor 1 , nilai Corrected Item-Total Correlation $=0,494>R$ tabel 0,3610, maka item soal no 1 tersebut valid. Apabila tidak valid saya akan membuang pernyataan tersebut dan tidak akan menjadi bahan penelitian serta tidak perlu melihat nilai Reliabilitas

Uji Persyaratan Analaisis diawali dengan uji normalitas, dari tabel 19 dengan melihat nilai Sig. pada kolom Kolmogorov-Smirnova. Pada contoh di atas nilainya 0,131 lebih dari 0,05, maka data berdistribusi Normal atau yang berarti menerima HO. Uji Linearitas Dari uji tabel 20 di atas mendapatkan hasil Linierity $0.000<0.05$ dan hasil Deviation from Liniearity $0.681>0.05$, maka variabel Koimtmen Organisasi memiliki hubungan yang linier atas variabel

\section{Loyalitas Organisasi}

Dari uji tabel 21 di atas mendapatkan hasil Linierity $0.000<0.05$ dan hasil Deviation from Liniearity $0.07>0.05$, maka variabel Koimtmen Organisasi memiliki hubungan yang linier atas variabel Loyalitas Organisasi. Dari uji tabel 22 di atas mendapatkan hasil Linierity $0.000<0.05$ dan hasil Deviation from Liniearity $0.01>0.05$, maka variabel Komitmen Organisasi memiliki hubungan yang non-linier atas variabel Keterikatan Karyawan.

Korelasi antar variabel. Syarat yang harus dipenuhi sebelum dilakukan pengujian model, data yang ada mempunyai korelasi yang signifikan antara variabel variabel yang terkait. Melalui penggunaan SPSS versi 25, diperoleh nilai korelasi antar variabel tersebut sebagaimana ditampilkan dalam tabel berikut: diperoleh informasi sebagai berikut : Koefisien korelasi komitmen organisasi (X1) terhadap loyalitas aktivs $(X 3)$ sebesar $r_{11}=0,749$. Koefisien korelasi Keterikatan kerja (X2) terhadap Loyalitas aktivis (X3) sebesar $r_{12}=0,487$. Koefisien korelasi Komitmen organisasi (X1) terhadap Keterikatan kerja $(X 2)$ sebesar $r_{11}=0,457$. Uji Hipotesis dan Pembahasan . Analisis korelasi bertujuan untuk melihat keeratan atau hubungan antara 2 variabel atau lebih. Korelasi antar variabel komitmen organisasi, keterikatan kerja dan loyalitas organisasi dapat dilihat pada tabel berikut ini :

Tabel 2 Koefisien Korelasi

\begin{tabular}{|c|c|c|c|c|}
\hline \multicolumn{5}{|l|}{ Correlations } \\
\hline & & $\begin{array}{l}\text { Komitmen } \\
\text { Organisasi }\end{array}$ & $\begin{array}{l}\text { Keterikatan } \\
\text { Kerja }\end{array}$ & $\begin{array}{l}\text { Loyalitas_- } \\
\text { Organisasi }\end{array}$ \\
\hline \multirow[t]{3}{*}{ Komitmen_Organisasi } & $\begin{array}{l}\text { Pearson } \\
\text { Correlation }\end{array}$ & 1 & $.676^{* *}$ & $.865^{\star \star}$ \\
\hline & Sig. (2-tailed) & & .000 & .000 \\
\hline & $\mathrm{N}$ & 78 & 78 & 78 \\
\hline \multirow[t]{3}{*}{ Keterikatan_Kerja } & $\begin{array}{l}\text { Pearson } \\
\text { Correlation }\end{array}$ & $.676^{* *}$ & 1 & $.698^{* *}$ \\
\hline & Sig. (2-tailed) & .000 & & .000 \\
\hline & $\mathrm{N}$ & 78 & 78 & 78 \\
\hline \multirow[t]{3}{*}{ Loyalitas_Organisasi } & $\begin{array}{l}\text { Pearson } \\
\text { Correlation }\end{array}$ & $.865^{* *}$ & $.698^{* *}$ & 1 \\
\hline & Sig. (2-tailed) & .000 & .000 & \\
\hline & $\mathrm{N}$ & 78 & 78 & 78 \\
\hline
\end{tabular}

Uji Hipotesis Komitmen Organisasi $\left(\mathbf{X}_{1}\right)$ terhadap Loyalitas $\left(\mathbf{X}_{3}\right)$ Hipotesis kesatu : $\rho_{31} \geq 0$ Diperoleh $\rho_{31}$ sebesar 0,725 maka $\mathrm{H}_{0}$ diterima artinya terdapat pengaruh langsung Komitmen Organisasi $\left(\mathrm{X}_{1}\right)$ terhadap Loyalitas Organisasi $\left(\mathrm{X}_{3}\right)$. Keterikatan Kerja $\left(\mathrm{X}_{2}\right)$ terhadap Loyalitas 
Organisasi $\left(X_{3}\right)$ Hipotesis kedua : $\rho_{32} \geq 0$ Diperoleh $\rho_{32}$ sebesar 0,207 maka $\mathrm{H}_{0}$ diterima artinya terdapat pengaruh langsung Keterikatan Kerja $\left(\mathrm{X}_{2}\right)$ terhadap Loyalitas Organisasi $\left(\mathrm{X}_{3}\right)$. Persepsi Harga $\left(X_{1}\right)$ terhadap Social Media Marketing $\left(X_{2}\right)$ Hipotesis ketiga : $\rho_{21} \geq 0$ Diperoleh $\rho_{21}$ sebesar 0,457 maka $\mathrm{H}_{0}$ diterima artinya terdapat pengaruh langsung positif signifikan Komitmen Organisasi $\left(\mathrm{X}_{1}\right)$ terhadap Keterikatan Kerja $\left(\mathrm{X}_{2}\right)$.

\section{Kesimpulan}

Pengujian hipotesis kesatu mengenai pengaruh Komitmen Organisasi $\left(X_{1}\right)$ terhadap Loyalitas Organisasi $\left(\mathrm{X}_{3}\right)$ pada aktifis Muhammadiyah PP Muhammadiyah kantor Jakarta dan aktifis organisasi otonom tingkat pusat menunjukkan bahwa terdapat hubungan dan pengaruh langsung positif serta signifikan antara Komitmen Organisasi $\left(X_{1}\right)$ dengan Loyalitas Organisasi $\left(X_{3}\right)$. Hal ini ditunjukkan dengan besarnya korelasi jalur sebesar 0,725 , hal ini menandakan tingkat korelasi kuat dan nilai signifikansinya $0.000<0,05$. Pengujian hipotesis kedua mengenai pengaruh Keterikatan Kerja $\left(\mathrm{X}_{2}\right)$ terhadap Loyalitas Organisasi $\left(\mathrm{X}_{3}\right)$ menunjukkan terdapat hubungan dan pengaruh langsung positif serta signifikan antara Keterikatan Kerja $\left(\mathrm{X}_{2}\right)$ dengan Loyalitas Organisasi $\left(X_{3}\right)$. Hal ini ditunjukkan dengan besarnya analisis jalur sebesar 0,207 bersifat tingkat korelasi rendah dan nilai signifikannya $0.000<0,05$. Pengujian hipotesis ketiga mengenai pengaruh Komitmen Organisasi $\left(\mathrm{X}_{1}\right)$ terhadap Keterikatan Kerja $\left(\mathrm{X}_{2}\right)$ menunjukkan bahwa terdapat hubungan dan pengaruh langsung positif signifikan antara Komitmen Organisasi $\left(X_{1}\right)$ terhadap Keterikatan $\left(X_{2}\right)$. Hal ini ditunjukkan dengan besarnya korelasi sebesar 0,457 bersifat tingkat korelasi sedang dan signifikan karena sig nya $0.000<0,05$.

\section{Referensi}

Anitha, J. (2014). Determinants of employee engagement and their impact on employee performance. International Journal of Productivity and Performance Management, 63 Iss 3, 308-323. http://www.sciepub.com/reference/136797

Haedar nashir. (2019). Agenda Muhammadiyah sangat berat. Suara Muhammadiyah, edisi 6.

Purnama, Jefri, Wahono, Budi, \& Khalikussabir. (2020). Pengaruh Budaya Organisasi, Motivasi Dan Komitmen Organisasi Terhadap Kinerja Organisasi (Studi Kasus Himpunan Mahasiswa Program Studi Manajemen, Akuntansi dan Perbankan Syariah Fakultas Ekonomi dan Bisnis Universitas Islam Malang). Jurnal Ilmiah Riset Manajemen, 09(01 Februari), 22-34. http://www.riset.unisma.ac.id/index.php/jrm/article/view/5581

Robinson D., S. Perryman, and S. H. (2004). The Drivers of Employee Engagement. Institute for Employment Studies. https://s3.amazonaws.com/academia.edu.documents/61605745/Employee_Engagement_Review_ SCMS_Journal20191225-22644-1fu7bbj.pdf?response-content-disposition=inline\%3B filename\%3DEmployee_Engagement_Key_to_Organizationa.pdf\&X-Amz-Algorithm=AWS4-HMACSHA256\&X-A

Sugiharto, L., \& Devie. (2015). Pengaruh Transformational Leadership Terhadap Financial Performance Perusahaan Melalui Employee Engagement Dan Job Satisfaction Sebagai Intervening Variable Pada Perusahaan Retail Terbuka Di Surabaya. Business Accounting Review, 3(1), 11-22. https://media.neliti.com/media/publications/185065-ID-pengaruh-job-satisfaction-terhadap-finan.pdf

Trianasari, Y. (2005). Hubungan Antara Persepsi Terhadap Insentif dan Lingkungan Kerja dengan Loyalitas Kerja. Fakultas Psikologi Universitas Muhammadiyah Surakarta. http://repository.maranatha.edu/9134/9/0951086_References.pdf. 